\title{
Short and Long-Term Impacts of Climate Change on Population Health in Yemen
}

\author{
Abdulsalam Saeed Al-Akel * \\ Senior Public Health Consultant \\ Assistant Prof. of Public Health \\ Faculty of Medicine, Sana'a University
}

\begin{abstract}
The study aimed to determine the levels to which the Yemeni population is vulnerable to the short and long terms adverse effect of climatic change. A qualitative assessment of vulnerability has been conducted through focus group discussion targeting the leadership and decision makers in the ministry of public health and population to know the extent of their knowledge about the level of the impact of climate change on the health of Yemeni population, in addition to the development of two baseline socioeconomic scenarios that have been linked to climate change scenarios projections. The results showed that both Yemen population growth and climate change are inevitably occurring and these two factors are the main determinants of vulnerability. Other factors that will determine future health vulnerability include; the current public health status, the age - sex structure of the population, socioeconomic development status and the political and security stability of government.Climate change synergized with the current massive war and low socioeconomic standards with deepening poverty and hunger would threat the progress and efforts of reducing the burden of climate-sensitive disease mainly vectorborne, waterborne and chronic non- communicable disease with the re-emerging of health-related diseases and injuries leading to deterioration of most health indicators. Population's health vulnerability to climate change and impact of climate change on population's health will be so severe in 2050 and 2100 under scenario A than Scenario B indicating the needs for sound and cost-effective adaptive strategies for the public health care sector.
\end{abstract}

Keywords: Climate Change, Vulnerability, Adaptation, Health, disease

DOI: $10.7176 / \mathrm{JEES} / 10-11-07$

Publication date: November $30^{\text {th }} 2020$

\subsection{INTRODUCTION}

Yemen is one of the least developed countries in the World and considered to be the driest and the poorest country in the Middle East. It is ranked 160 out of 188 countries in 2014 on HDI. The annual GDP has averaged 3-4\% between 2000 to 2010 and deteriorated after the 2010's (UNDP/ Yemen HDR. 2015). Poverty in Yemen is endemic and has been increased from $42 \%$ in 2009 , to $54.5 \%$ in 2012 to more than $85 \%$ in July 2016 (WB, 2016). A shrinking resource base coupled with already low productivity and internal conflict place enormous pressure on social and economic systems of Yemen's and contributes further to increasing poverty (HNO, 2016).

Yemen's population, scattered over 130,000 localities, is expected to increase from 27.534 million in July 2016 to 47.17 million in 2050 and to 51 million in 2100 (World Population Review, Yemen, 2016). More than $40 \%$ of the population below the age of 15 years, $57.1 \%$ of the population is between $15-64$ years of whom $24.9 \%$ are women in the childbearing age group (15 - 49 years) and only $3.2 \%$ are aged 65 years and above of whom $1.2 \%$ above 70 years. About two third of the population (including 80 percent of the poor) live in rural areas and most of them depend on agriculture for their livelihoods (UN Population Division, Yemen. 2016). In addition, more than $45 \%$ of the population suffers from high illiteracy (UNESCO, 2012) with only 8.6 percent of adult women have reached at least a secondary level of education compared to 26.7 percent of their male counterparts (UNDP, HDR Yemen, 2015).

Hunger and undernutrition are widespread ranking the country the $11^{\text {th }}$ most food insecure globally with $32 \%$ of the population food insecure. One in three Yemenis are acutely hungry and with no sufficient resources to access nutritious food necessary for healthy and productive life. Half of the country's children are chronically undernourished; 320,000 children are severely undernourished and less than 1 in 10 children live to reach the age of 5 years. Such emergency levels of chronic undernutrition have caused 53\% (63\% among poor) of Yemeni children under five to be stunted placing Yemen second to Afghanistan and the third highest on the World after India and Bangladesh in underweight (WFP, 2015). (4 5 Year Strategic Plan).

Yemen also suffers from severe water scarcity. In 1955, Yemen's per capita water availability was $1,098 \mathrm{~m}^{3}$; fallen in 1990 to $460 \mathrm{~m}^{3}$ and is projected to drop to $150 \mathrm{~m}^{3}$ by 2025 (Nicole Glass, 2012). In 2014, only $31 \%$ of the population were having access to pure drinking water while sanitation services were available for only $23 \%$ (Health Statistic Report, 2014).

Yemen's political instability, civil insecurity, intensified war, and localized conflicts have plunged the country into a serious food security and humanitarian. The estimated number of people in needs of any kind of humanitarian assistance in 2015 exceeded 21.2 million (82\% of the total population) and the severity of needs 
among vulnerable people has been intensified across all developmental sectors. Nearly 19.3 million lack adequate access to clean water or sanitation, 14.1 million people lack sufficient access to basic healthcare, 3 million children and pregnant or lactating women require malnutrition treatment or preventive services and IDPs has raised to nearly three million (HNO, Yemen, 2016).

Health indicators for Yemenis still very poor. Life expectancy at birth reached 63.8 years (UNDP, HDR. Yemen, 2015). Infant mortality rate ad under-5 mortality rate is estimated 48.6 per 1,000 and 53 per 1,000 live births respectively but varies with sex and place of residence as higher in female and in rural areas and for every 100,000 live births, 270 women die from pregnancy related causes (DHS, Yemen. 2013). The most common and serious health conditions ad causes of the current morbidity and mortality are diarrhea, upper and lower respiratory infections, malaria (these diseases cause $86.2 \%$ of the total burden of disease), bilharzias, TB, malnutrition, mumps, viral hepatitis, anemia, intestinal parasites, accidents of all kinds and cardiovascular diseases (Statistical Health Report, 2016).

Climate change and its consequences is another emerging and pressing development challenges facing Yemen. Though Yemen is not contributing a lot into the anthropogenic GHG emissions and its GHG emissions nearly negligible (about 0.1 percent of the aggregated World total), but still highly vulnerable to climate change - related impacts (INDC, 2015). In 2001, Yemen's Initial National Communication (INC) to the United Nation Framework Convention on Climate Change (UNFCCC) reported that an increased climatic variability would lead to the possibility of spread and growth of vector borne, and water borne diseases (EPC, 2001 \&NAPA, Yemen. 2009). Yemen is a disaster-prone country and faces a number of natural hazards, and climate-related hazards such as extreme temperatures, floods, landslides, sea level rise and droughts, with floods being the most important and recurring form of disasters, are inevitably occurring (CRED, 2011). Exposure to these climate related hazards are expected to severely exacerbate health problems such as vector borne and waterborne diseases which may extend their range into areas that are presently unaffected as well as chronic diseases such as cardiac, respiratory and renal disease.

All population are vulnerable to health impact of climate change but the impact is expected to be more severe in children, the poor people, especially women and particularly pregnant women, elderly people and people with chronic medical conditions and disabilities. The impact of climate change on health can occur directly as a result of changes in temperature and precipitation and occurrence of heat waves, floods, droughts, and fires, and indirectly through ecological disruptions brought on by climate change on crop failures, shifting patterns of disease vectors, or on social responses to climate change such as displacement of populations following prolonged drought (Smith et al., 2014).

The main objective of this study is to to determine the levels to which the Yemeni population is vulnerable to the short and long terms adverse effect of climatic change and to identify options for adaptation measures through a participatory mechanism with relevant stakeholders.

\section{Literature Review}

Climate change is already having an impact on the global burden of morbidity and mortality and such effects are likely to increase all around the globe (IPCC $4^{\text {th }}$ Assessment report, 2007). These impacts that vary in extent and nature depend on local environmental conditions, socio-economic circumstances, and the range of adopted social, institutional, technological, and behavioral measures (IPCC, 1998; Patz and Kovatz, 2002; 2007, WHO, 2008a).

Climate change is adversely affecting the health of populations around the world, with the greatest impacts in low-income countries (Confalonieri et al., 2007; McMichael et al., 2003a; WHO, 2002, 2009). 2.5 million people die every year from non-infectious diseases directly attributable to environmental factors such as air pollution, stressful conditions in workplaces, exposure to chemicals such as lead, and exposure to environmental tobacco smoke. 3.5 million death from malnutrition, 1.8 million from diarrhoea that largely resulted from lack of access to clean water supply and sanitation, and from poor hygiene, and approximately 60,000 in natural disasters (WHO, 2006 and WHO, World health day 2008).

The Eastern Mediterranean Region, including Yemen, is one of the most vulnerable regions to climate change because of its arid nature and reliance on rain-fed food production' and because of the endemic nature of many diseases and health problems which are sensitive to poverty and climate change, making the impact of climate change on this region greater than that on the world as a whole (Fankhauser and Tol, 1997, WHO/EMRO, 2008a),

Yemen is chronically suffering from very weak economy, high levels of poverty rates, weak institutional capacities, lack of the necessary resources for adaptation, high and rapid population growth, poor management of available and scarce resources (NHS,2010 - 2025). These factors will make Yemen extremely vulnerable to the effects of climate related change such as drought, extreme flooding, pests, sudden disease outbreaks, changes of rainfall patterns, increased storm frequency/severity and sea level rise (Yemen Proposal for Phase 1, 2010).

Climate change may affect mental health directly by exposing people to trauma, and may also affect mental health indirectly, by affecting physical health (for example, extreme heat exposure causes heat exhaustion in vulnerable people, and associated mental health consequences (Berry et al., (2010). Mortality is associated with 
high ambient temperature for population subgroups from cardiovascular, with the most significant risk for ischemic heart disease. The elevated risks for persons are associated with at least 65 years of age, infants one year of age or less and the Black racial/ethnic group but no differences in relation gender or educational level (Basu et al., 2008). Exposure to extreme and prolonged heat is associated with heat cramps, heat syncope, heat exhaustion, and heatstroke (McGeehin and Mirabelli, 2007). Temperature and humidity are strongly correlated with the number of heat strokes dealt with at the hospital emergency unit, and maximum temperature alone was a better predictor of heatstroke than maximum humidity alone (Shanks et al., 2001).

Heat wave in France in August 2003 were the main epidemiological features of the major increase in mortality rates. Excess mortality was increased markedly with age above 35 years and it was $15 \%$ higher in women than in men of comparable age as of age 45 years and deaths directly related to heat, heatstroke, hyperthermia and dehydration increased massively. Cardiovascular diseases, ill-defined morbid disorders, respiratory diseases and nervous system diseases also markedly contributed to the excess mortality (Fouillet et al, 2006).

The majority of European studies have shown that women are more at risk, in both relative and absolute terms, of dying in heatwaves. Other studies have also shown that unmarried men tend to be at greater risk than unmarried women, and that social isolation, particularly of elderly men, may be a risk factor (Gender, Climate Change and Health, WHO report, 2011).

Globally, natural disasters such as droughts, floods and storms kill more women than men, and tend to kill women at a younger age. These effects also interact with the nature of the event and social status. The gender-gap effects on life expectancy tend to be greater in more severe disasters, and in places where the socioeconomic status of women is particularly low (Gender, Climate Change and Health, WHO report, 2011). Higher temperature is associated with shorter gestation and higher ambient temperatures in the last four weeks of the pregnancy increase the risk of stillbirth (Strand et al., 2012)

Climate-sensitive health impacts, such as undernutrition and malaria, show important gender differences. Gender differences occur in health risks that are directly associated with meteorological hazards. These differences reflect a combined effect of physiological, behavioural and socially constructed influences (Gender, Climate Change and Health, WHO report, 2011). Temperature and rainfall may be used as key meteorological predictors for the number of cases of Salmonella (Zhang, Y., P. Bi, and J.E. Hiller, 2010).

Greater incidence of flooding, which may occur due to climate variability, poses the risk of diarrhoea and gastroenteritis; skin and eye Infections; acute respiratory infections; and malaria. Exposure to drought poses the potential health risks in the form of food insecurity and malnutrition; anaemia; night blindness; and scurvy. Increases in temperature pose health risks of heat stroke; malaria; dengue; respiratory diseases; and cardiovascular diseases. The most deprived regions in terms of socio-economic indicators is mostly affected (Malik, S.M., H. Awan, and N. Khan, 2012). Mortality risk depends on storm intensity, quality of governance, and levels of poverty (Peduzzi et al., 2012). Rural population in developing countries that rely on subsistence farming in low rainfall areas are at high risk of undernutrition and water-related diseases if drought occurs (Acosta-Michlik et al, 2008).

Populations with already "poor sanitation infrastructure and high burdens of infectious disease often experience increased rates of diarrheal diseases after flood events" (IPCC, 2007). Changes in climatic conditions and climate variability represent a further factor which can affect human health directly or indirectly via changes in biological and ecological processes that influence the transmission of several infectious diseases (WHO, 2003).

Estimating vulnerabilities of least-developed countries to climate-related extreme events over the next 50 year, found that countries with a higher Human Development Index (HDI) per capita-are less affected by the floods, droughts, and cyclones (Patt et al., 2010). The largest absolute numbers of maternal deaths occur in countries with a total fertility rate of greater than four and the combination of global warming and rapid population growth in the Sahel and parts of the Middle East may be particularly vulnerable to climate change because it already suffers so much stress from rapid population growth, chronic drought, and governmental instability (Potts, M. and C.E. Henderson, 2012). Victims of floods are at high risk of malnutrition, diarrhea and other water-borne diseases, and diseases caused by crowding and lack of hygiene (WHO, 2007).

$42 \%$ of the global malaria burden, or half a million deaths annually, could be prevented by environmental management, although this proportion varies significantly across different regions. (WHO, 2006). In a study of climate change and health in sub-Saharan Africa, health impact of individuals will face multiple stresses from climate change such as floods and malaria, concomitant with other non-climate stressors (Ramin, B.M. and A.J. McMichael, 2009). Malaria re-emergence in Huang - Huai River of Central China, the annual average temperature and rainfall may have close relationship with annual incidence of malaria cases (Zhou et al 2010).

Infectious agents lack a thermostatic mechanism, making their reproduction and survival highly dependent on fluctuations in climate (Saab, 2009). Children and pregnant women are at a higher risk of contracting malaria. Pregnant women are susceptible to malaria with adverse outcomes of low birth weight and maternal anemia (WHO, $2008 \mathrm{c}$ ). Severe pediatric malaria, which is endemic to the coastal plain of Yemen as well as to the inland mountains, is a substantial burden to health services in Yemen (Al- Taiar et al., 2006; 2008).

Climate change is projected to influence the geographical distribution and intensity of transmission of malaria, 
due to changing patterns of rainfall, humidity and particularly seasonal variation of temperature (IPCC, 2007). The falciparum malarial protozoa were found to takes 26 days to incubate at a temperature of $25 \mathrm{C}$, while at a temperature of $26 \mathrm{C}$ this same protozoon takes only 13 days to incubate (Epstein, 2004). 3\% increase in temperature in a certain region in East Africa can mean an increase of 30-40\% of mosquito abundance (Khamsi, 2006). Transmission of malaria occurs throughout the year in Saudi Arabia with peaks associated with the rainy season and hot summers (Malik et al.,1998). Significant associations between climatic factors such as temperature, relative humidity, rainfall volume and wind speed with incidence of malaria (Al- Mansoob and Al-Mazzah, 2005). Favorable meteorological conditions (i.e., optimum temperature and relative humidity) led to the prolongation of the malaria transmission season to 8 months a year in Fayoum Governorate in Egypt (Bassiouny,2001). Dengue hemorrhagic fever and shock syndromes is no longer confined to the tropics and is a global disease (Ranjit, S. and N. Kissoon, 2011)

\section{Research Design and Methodology}

The impacts of climate change on human health would occur through pathways of varying complexity, scale and directness and with different timing. These impacts vary in extent and nature depending on local environmental conditions, socio-economic circumstances, and the range of adopted social, institutional, technological, and behavioral measures (IPCC, 1998; Patz and Kovatz, 2002; 2007, WHO, 2008a).

A modified Driving Force, Pressure, State, Exposure, Effect, Action (DPSEEA) Framework and its relationship with health impacts of climate change will be used in the current assessment to describe the actions of various causes that act, more or less directly, on health outcomes from environmental or related behavioral conditions and the various levels of actions that can be taken to reduce health impacts (Corvalan et al., 2000). Driving forces as agriculture, transport policies, land use change and urbanization process of DPSEEA framework will not be investigated.

Table (1): Driving Force, Pressure, State, Exposure, Effect, Action (DPSEEA) Framework

\begin{tabular}{|c|c|}
\hline & Actions \\
\hline $\begin{array}{c}\text { Driving forces } \\
\text { Energy, agriculture, transport policies; Demographic change; land-use } \\
\text { change; urbanization process }\end{array}$ & $\begin{array}{l}\text { International agreements } \\
\text { (e.g., Un Conventions: UNFCCC, } \\
\text { CBD, CCD) }\end{array}$ \\
\hline $\begin{array}{c}\text { Pressures } \\
\text { Greenhouse gas emissions }\end{array}$ & National mitigation policies \\
\hline $\begin{array}{c}\text { State } \\
\text { Climate change }\end{array}$ & $\begin{array}{l}\text { Adaptation policies and } \\
\text { programs to manage risks }\end{array}$ \\
\hline $\begin{array}{c}\text { Exposure } \\
\text { Extreme weather events (droughts, floods, heat waves); ecosystem } \\
\text { changes; water scarcity; food availability; } \\
\text { changes in vector distribution }\end{array}$ & $\begin{array}{l}\text { Indicators; monitoring; } \\
\text { surveillance systems; public } \\
\text { health policies; environmental } \\
\text { protection }\end{array}$ \\
\hline $\begin{array}{c}\text { Effect } \\
\text { Climate-sensitive diseases including cardiovascular; acute and chronic } \\
\text { respiratory; acute diarrhoeal; } \\
\text { mental; vector-borne; malnutrition; injuries }\end{array}$ & Diagnosis and treatment \\
\hline
\end{tabular}

The methodology of assessment of the short- and long-term impact of climate change on Yemeni population health will be based on four stages:

\subsection{First stage: Focus Group Discussion for Vulnerability and Adaptive Capacity Assessment}

The vulnerability of a population group is the combination of its sensitivity to climate change and its ability to adapt to the projected climate change factors. Vulnerable population and climate hazards will be merged in each vulnerability determinant so as to give a clear picture of the magnitude of climate hazards on those vulnerable groups. This will be assessed through qualitative FGD with decision makers of the MoPHP. The dimensions of the FGD are divided into four parts that included 12 climate change health related issues. The four dimensions are: general information on climate change, climate change events affected Yemen, the extent of the impact of climate change on population health, and the adaptive measures of the health sector.

A list of 95 of decision makers in the MoPHP was identified and divided into nine groups that varied in numbers and members according to the availability of the decision makers. The 9 groups included minister advisors, deputy's minister, general directors, primary health care program's directors and directorate directors.

\subsection{Second Stage: Development of Two Socioeconomic Scenarios}

The development of two baseline socioeconomic scenarios had been linked to climate change scenarios projections taking into consideration changes in temperature and precipitation levels. The two socioeconomic scenarios were 
built depending on the demographic and socioeconomic factors related to 2010 as a base year, for and the projected demographic status of the population in 2050 and 2100. The current socioeconomic situation has not been used in the two scenarios because these indicators have changed dramatically between 2010 and 2015 due to the existed war and its consequences.

\subsubsection{Characteristics of Socioeconomic Scenarios A}

Socioeconomic Scenario A was built from the following building blocks:

1. Population growth will continue steadily at an increasing rate till 2050 but the growth will be declined between $2050-2100$

2. Poor economic development

3. Low growth of GDP.

4. Low preparedness/ low prevention measures and adaptive capacity of the health care system and the population

5. Poor quality and scarcity of health care services.

6. Availability and accessibility to pure water resources will be of great challenge

7. Deterioration of living standards (sanitation, electricity, education and housing)

\subsubsection{Characteristics of Socioeconomic Scenario B}

Socioeconomic scenario B was built from the following building blocks:

1. Population growth will continue at the low projection variant where fertility rate will be decreased to 3.3 per women by 2025 to 2 children per women by 2035

2. Improved economic development. Political and security situation will be improved and oil and gas extraction will be increased in the expected sites. Governance and autonomy will be established and strengthened.

3. GDP growth will increase up to $5 \%$ annually due to oil revenue and political stability.

4. Local governance will increase the preparedness and prevention measures and so the adaptive capacity of the health care system.

5. Improved quality and availability of health care services.

6. Availability and accessibility to pure water resources will be of great challenge

7. Living standards will be improved (sanitation, electricity, education and housing)

\subsection{Third Stage: Development of Climatic Change Scenarios}

Long-term systematic observations of precipitation and temperature data are very scarce in Yemen. There are recognized quality concerns associated with daily and monthly meteorological record. Meteorological data are not held by a central authority and they are collected by several authorities which will hamper any efforts in quantifying the long-term changes in climate. Without homogeneous rainfall and temperature records, it will be hard to benchmark future climate variability and change, or the associated impacts. (Rob Wilby, 2009). Therefore, this stage will involve the development of a climate change scenarios from available literature reviews.

\subsubsection{Precipitation Projection}

Projections of future rainfall disagree with all models, with some models projecting increases in rainfall while other models project decreases in some models. These large uncertainties in future rainfall patterns are in part a function of differences in model behavior of the Inter - Tropical Convergence Zone. There is, however, broad consistency between models in projecting increases in September, October, and November (SON) rainfalls, with the range of projections spanning small decreases and large increases ( $-14 \mathrm{~mm}$ to $+49 \mathrm{~mm}$, or -21 to $+265 \%$ ). The proportion of rainfall that falls in 'heavy' events shows an increase for autumn (SON) in most model projections with an increased risk of floods and drought and is projected to change by $-21 \%$ to $+23 \%$ by the 2090s. The maximum 1 - and 5 - day events in SON are projected to change by -6 to $+19 \mathrm{~mm}$, and - 13 to $+37 \mathrm{~mm}$ respectively by the $2090 \mathrm{~s}$.

\subsubsection{Temperature Projection}

A country-average annual temperature series for Yemen shows warming of $0.5^{\circ} \mathrm{C}$ throughout the entire $20^{\text {th }}$ century. However, over the period 1961-1990 local rates of warming have been greater, especially at higher elevation sites. The equivalent rates of $6.1^{\circ} \mathrm{C}, 5.4^{\circ} \mathrm{C}$ and $4.8^{\circ} \mathrm{C}$ per century were observed at Sana'a $(2200 \mathrm{~m})$, Seyoun $(700 \mathrm{~m})$ and Hodeida $(10 \mathrm{~m})$ respectively.

The mean annual temperature is projected to increase by 1.2 to $3.3^{\circ} \mathrm{C}$ by the $2060 \mathrm{~s}$, and 1.6 to $5.4{ }^{\circ} \mathrm{C}$ by the $2090 \mathrm{~s}$. The range of projections by the $2090 \mathrm{~s}$ under any one emissions scenario is around 1.5 to $2.0^{\circ} \mathrm{C}$. The projected rate of warming is similar in all seasons, but it is more rapid in the interior regions than areas close to the coast.

\subsection{Fourth Stage: Assessment of the Impact of Climate Change on Population Health}

In the fourth stage, the impacts of climate change on the public health of Yemeni population will be analyzed by combining both sensitivity and exposure of the population groups to the climatic change. Climate-related hazards 
include extreme temperatures, floods, landslides, sea level rise and droughts. While these hazards are natural occurrence in Yemen, they nevertheless pose serious constraints on development and food security. The extent and nature of climate change impacts on human health depend on their intensity, duration and frequency of the exposure and the ability to adapt to or cope with these changes.

\section{Finding and Results}

\subsection{Findings of Focus Group Discussion for Assessment of Vulnerability}

\subsubsection{General Information About Climatic Changes}

Analysis of FGD reports with the decision makers of the ministry of public health and population (MoPHP), found that one third of the health sector decision makers have a very good knowledge about climate change while less than one tenth has an excellent knowledge.

\subsubsection{Population Group and Geographical Areas Most Vulnerable to Climate Change}

Eight out of ten of decision makers strongly belief that climate change will pose certain risk on different population groups mainly children followed by the believe of seven out of ten of the decision makers that elderly will be mostly affected, then pregnant women and displaced and refugees, while four out of ten and two out of ten of decision makers respectively believed that women and men are the least to be affected by climate changes.

Though seven out of ten of participants believe that the highest severity of climate change will be expected in coastal areas and Islands, only slightly higher than three in ten believe that the cities will be affected by climate change, followed by desert and mountain regions. These findings, to some extents, are in line with the international literature and the table below shows the different vulnerable population group.

Table (2): different population's groups vulnerable to the health impacts of climate change

\begin{tabular}{|c|c|}
\hline Vulnerability due to demographic factors & $\begin{array}{l}\text { Proportion of children under } 5 \text { years } \\
\text { Proportion of women in the childbearing period } \\
\text { Proportion of pregnant women } \\
\text { Proportion of elderly population group } 65 \text { years and above } \\
\text { Population density }\end{array}$ \\
\hline Vulnerability due to health status & $\begin{array}{l}\text { Populations with infectious disease } \\
\text { Population living in high risk area of epidemics } \\
\text { Populations with tuberculosis (TB) } \\
\text { Undernourished populations } \\
\text { Populations with chronic disease } \\
\text { Mentally or physically disabled people }\end{array}$ \\
\hline $\begin{array}{l}\text { Vulnerability due to culture or life } \\
\text { condition }\end{array}$ & $\begin{array}{l}\text { Displaced populations } \\
\text { Poor people } \\
\text { Nomadic peoples } \\
\text { Subsistence farmers (see agricultural lands owner) } \\
\text { Low earning laborers }\end{array}$ \\
\hline $\begin{array}{l}\text { Vulnerability due to limited access to } \\
\text { adequate resources and services }\end{array}$ & $\begin{array}{l}\text { Poorly and Unplanned urban housing } \\
\text { Drought risk areas } \\
\text { Conflict areas } \\
\text { Water-stressed areas } \\
\text { Food-insecure population } \\
\text { Urban areas } \\
\text { Population living in rural and remote areas }\end{array}$ \\
\hline $\begin{array}{l}\text { Vulnerability due to limited access to } \\
\text { adequate essential services }\end{array}$ & $\begin{array}{l}\text { Health care } \\
\text { Potable drinking water } \\
\text { Sanitation } \\
\text { Education } \\
\text { Shelter (most live in poor housing conditions) } \\
\text { Economic opportunities (low income and Indentured) }\end{array}$ \\
\hline $\begin{array}{l}\text { Vulnerability due to sociopolitical } \\
\text { conditions }\end{array}$ & $\begin{array}{l}\text { Political stability } \\
\text { Existence of complex emergencies or conflict } \\
\text { Freedom of speech and information }\end{array}$ \\
\hline
\end{tabular}

Source: Joy Guillemot, WHO. (Modified)

\subsubsection{Climate Change Events Affected Yemen}

Ranking of events related to climate changes that had affected Yemen according to their level of importance and the severity of their impact on population health have shown that two thirds of participated decision makers in the FGD, and half of the decision makers participated in the FGD believed that high temperature is the most important 
factor of climate change that will affect severely the population health, followed by the amount and intensity of rain and floods, while drought, low temperature, sandstorms and changes in humidity levels were the least factors to affect the population health. These finding are in accordance to the WHO report, stating that the region, including Yemen, is one of the most vulnerable regions to climate change because of its arid nature and reliance on rain-fed food production' and because of the endemic nature of many diseases and health problems (WHO/EMRO, 2008a).

\subsubsection{Climate Change Impact on Public Health issues}

Nearly all decision makers in the MoPHP participated int FGD believed that climate change will have a great negative impact on population health and this would be one of the main emerging issues to be considered among decision makers when planning for health care.

\subsubsection{Impact of Climate Change on Infectious Diseases}

In regards to vectorborne diseases (VBDs), nearly all decision makers in the MoPHP believed that climate change will have a profound effect on communicable diseases with major impact of climate change on infectious and chronic disease. Eight of ten of decision makers expected that the impacts will be the heavily increased in the incidence and prevalence of malaria, followed by the same degree for increased incidences of dengue fever.

With respect to food and waterborne infections, Yemen is highly vulnerable to floods, droughts, heavy storms, changes in rain pattern, increase of temperature and sea level (NAPA, 2009), all of which will affect the biological, physical and chemical components of water through different paths and thus enhancing the risk of waterborne diseases. Nine out of ten of decision makers in the MoPHP believe that diarrheal and other waterborne diseases will be greatly increased by climate change, and nine out of ten of decision makers expect that the incidence of cholera cases will be markedly increased due to climate change, and eight out of ten of decision makers expect typhoid and paratyphoid will be increased greatly.

\subsubsection{Impact of Climate Change on Non-communicable Diseases}

Nearly eight of ten of decision makers believe that climate change will lead to an increase rate of respiratory diseases and five out of ten and four out of ten of decision makers believe that climate change will increase the incidence rates for skin diseases and kidney and heart diseases respectively. Slightly more than half of the participants believed that climate change will have significant impact on skin diseases and psychological stress and anxiety, and only less than two out of ten of the participants believed that climate change would increase the incidence rate of diabetes mellitus. Eight of ten of decision makers believe that malnutrition will be aggravated by climate change so as low weight and stunting.

\subsubsection{Findings of Focus Group Discussion for Assessment of Adaptation Strategies}

Adaptive strategies of the health sector to cope with climate change and reduce their impacts are very weak from the perspective of decision makers of the MoPHP. While slightly more than eight in ten believed that the adaptive capacity of the health sector to cope with the adverse effect of climate change is medium in the area of human resources capacity, it is weak in areas of technical skills, infrastructure and very weak in the areas of financial resources, institutional networking and legal frameworks.

\subsection{Finding from Analysis of the Two Socioeconomic Scenarios}

\subsubsection{Population Growth and Size}

Population will continue to grow at steady speed even though the fertility rate might be decreased markedly, and this growth in size will come mainly from the already existed youth population who form nearly $40 \%$ of the total population a phenomenon known as population momentum. According to medium variant projection, population size will increase by nearly 23 million between 2010 - 2050 before it starts to a stabilize growth between 2050 2100 where the increase in the total size will not exceed 4.5 million. The projected population growth between $2010-2100$ is shown below.

Figure (1): The projected population growth between $2010-2100$

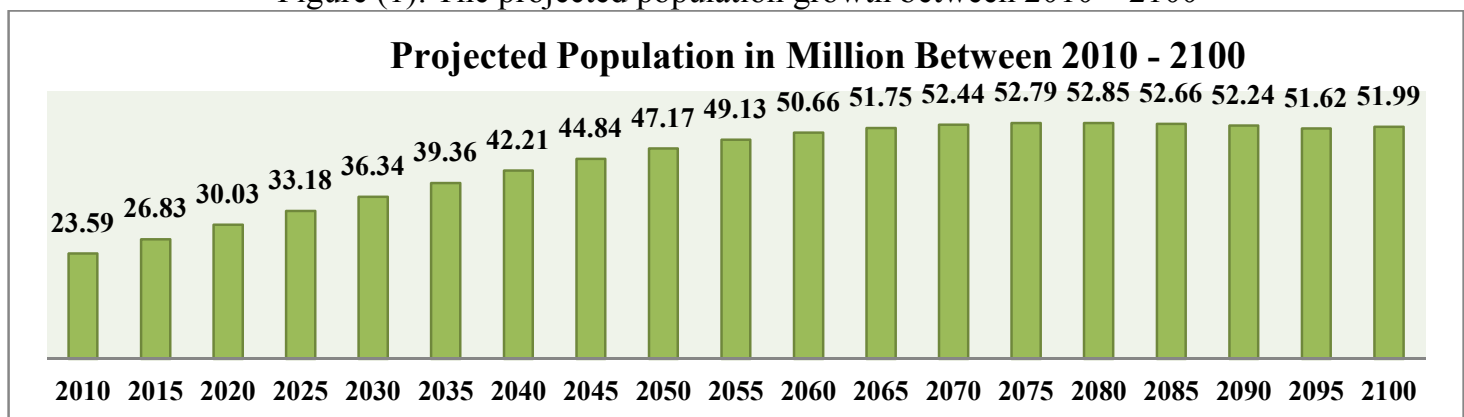

4.2.2. Economic Development

Yemen is one of the poorest countries in the World and its economy depends on foreign aid and remittances from 
workers in neighboring Gulf States. The economy is dominated by the oil sector, which accounts for $27 \%$ of the gross domestic product (GDP) and 70\% of export revenues. Agriculture forms also a very important sector as it employs over $50 \%$ of the population.

Before 2010, the government has engaged in efforts to diversify the economy from dependency on oil, and as a result, there was a surge of investment in the development of infrastructure for natural gas extraction. Yet, the political instability in 2011 has undermined development efforts, resulting in damage of infrastructure, rising unemployment, high inflation, depletion of oil reserves and ongoing disruptions at oil production facilities with decline in exporting oil and gas which stopped completely in 2015, all of which led to the marked recent decline in oil revenues causing severe fiscal difficulties.

The budget deficit grew to about 10 percent of GDP in 2009, and is expected to increase much higher in the coming years with cut of all running cost from mid-2015 for all government institutes and organizations. Yemen also has the lowest level of official development assistance (ODA) per capita at \$12.70, or just 2.2 percent of GDP, compared to $\$ 33.40$ per capita (18.7 percent of GDP) for the other least developed countries in the World.

\subsubsection{Gross Demotic Product Growth Rate}

The Gross Domestic Product (GDP) in Yemen contracted by 28.10\% in 2015 from the previous year. GDP Annual Growth Rate in Yemen averaged 1.06\% from 2001 until 2015, reaching an all-time high of 7.70\% in 2010 and a record low of $-28.10 \%$ in 2015 as seen below (Central Statistics Office Data Base, 2015)

Figure (2): GDP Annual Growth Rate in Yemen 2006 - 2015

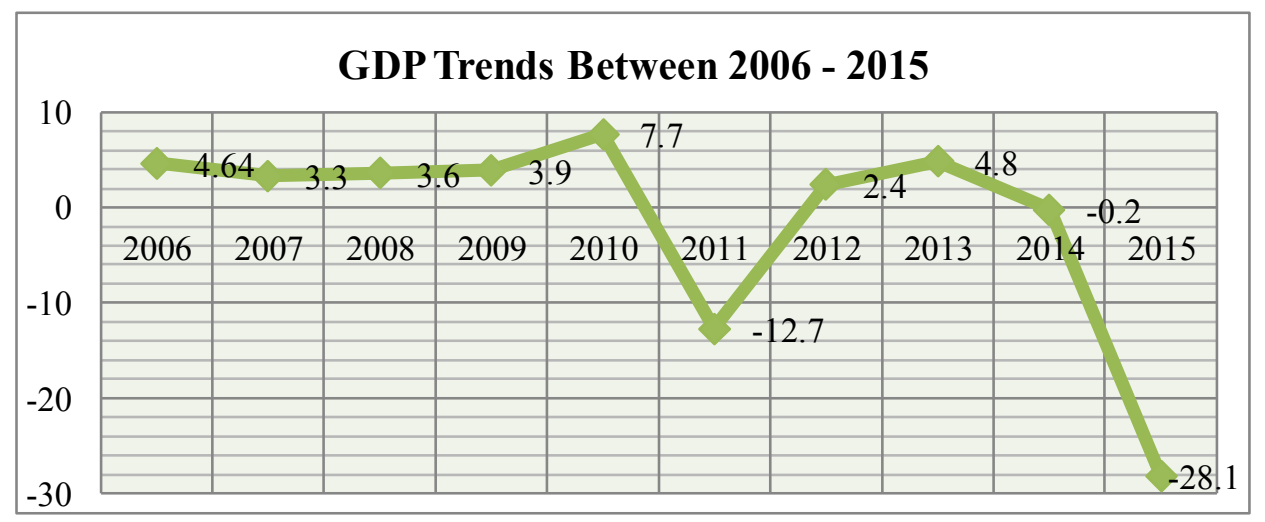

\subsubsection{Health Care Coverage}

The current health care conditions will not be improved and heath indicators will be deteriorated as a consequence of population growth, low socioeconomic growth, war and the protracted crisis. Increase in population size implies low growth in the demand for health services and low growth in hospital admissions in cases of emergency and the low GDP growth entails higher reliance on public provision of health services.

\subsubsection{Basic Infrastructures Services (pure water supply and sanitation)}

Scarcity of water will be increasing with time as Yemen is a very scarce water country and the per capita availability is falling steadily with growing population. With the current socioeconomic situation, the current $31 \%$ of the population who have access to pure drinking water will not be increased so as with sanitation services. A part from households need and usage, water is heavily needed for industry and agriculture which form the two main pillars for modern economy and economic growth. The equation is hard to be balanced between the rapid growth of the population and the increase demand on water in a scarce environment and this will be exacerbated if industrial or agricultural fields are planned to improve the economy.

\subsubsection{Governance}

Good governance aims at rationalization of political, economic power and decision-making. The future of governance in Yemen is so dull due to the very poor and weak governing institutions and values and the overwhelming current situation that will have its implications for so many decades and will be subjected and influenced to a great extent by developments in the current conditions. At times of political and security stability, health sector was never being of a priority concern for all previous governments and suffered from various challenges and crisis. In the coming years there might be the will to improve the population health but certainly the priorities will not be towards protecting the health of the population from the adverse effect of the climate change. Sustainable economic development and generation of financial resources and revenues will grow so slowly against an accelerated population growth so the allocated resources for health will be decreased.

\subsection{Assessment of Vulnerability, Sensitivity and Adaptive Capacity under Socioeconomic Scenarios} Under Scenario A, the vulnerability of human health to climate change will be higher than in Scenario B. The assumptions under Scenario A are based on high and rapid population growth which will have its consequences on population composition by age and sex which will be reflected on higher demands on already weak and poor 
public health services and essential infrastructure services such as education, water, sanitation, energy and housing. The increased numbers of those with food insecurity and undernourished people will exacerbate the population health and would lead to aggravation of poverty and people in needs. In addition, the low GDP growth would entail an unequal access to health services causing marked disparities among all segments of the population regardless of gender, residential or economic status. Both, rapid population growth and low GDP growth will undermine the opportunities for the adaptive capacities and coping options especially among vulnerable groups. On the other hand, the assumptions of Scenario B are characterized by the balanced population growth, the raised GDP growth, economic development, improvement of the environment of governance and the rules of laws and orders, peace and security all of which would improve the current health conditions along with the standards of living. Prevention and control measures, proper preparedness and emergency strategies in the health care system would lead to better health services leading to higher adaptive capacity of the population groups. The table below summarizes sensitivity, vulnerability and adaptive capacity assessment of population groups under socioeconomic scenarios.

Table (3): Vulnerability, sensitivity of population groups and adaptive capacity

\begin{tabular}{|c|c|c|c|}
\hline $\begin{array}{l}\text { Population } \\
\text { group }\end{array}$ & Sensitivity to climate change & Adaptive capacity & Vulnerability \\
\hline \multirow[t]{2}{*}{ Children } & \multirow{2}{*}{$\begin{array}{c}\text { High sensitivity to thermal stress and } \\
\text { extreme weather events }\end{array}$} & Scenario A: Very low & Very high \\
\hline & & Scenario B: Low & High \\
\hline \multirow[t]{2}{*}{ Women } & \multirow{2}{*}{$\begin{array}{l}\text { High sensitivity to thermal stress and } \\
\text { extreme weather events }\end{array}$} & Scenario A: Very Low & Very High \\
\hline & & Scenario B: Low & High \\
\hline \multirow[t]{2}{*}{ Pregnant Women } & \multirow{2}{*}{$\begin{array}{l}\text { High sensitivity to extreme weather } \\
\text { events, heat and floods }\end{array}$} & Scenario A: Very Low & Very High \\
\hline & & Scenario B: Low & High \\
\hline \multirow[t]{2}{*}{ Elderly people } & \multirow{2}{*}{$\begin{array}{l}\text { High sensitivity to thermal stress and } \\
\text { extreme weather events }\end{array}$} & Scenario A: Very Low & Very High \\
\hline & & Scenario B: Low & High \\
\hline \multirow{2}{*}{$\begin{array}{l}\text { Population with } \\
\text { low SES }\end{array}$} & \multirow{2}{*}{$\begin{array}{l}\text { High sensitivity to chronic diseases and } \\
\text { heat stress }\end{array}$} & Scenario A: Very Low & Very High \\
\hline & & Scenario B: Low & High \\
\hline \multirow{2}{*}{$\begin{array}{l}\text { Outdoor working } \\
\text { laborers }\end{array}$} & \multirow{2}{*}{$\begin{array}{c}\text { High sensitivity of certain occupations } \\
\text { to heat-related outcomes }\end{array}$} & Scenario A: Very Low & Very High \\
\hline & & Scenario B: Low & High \\
\hline \multirow[t]{2}{*}{ IDPs } & \multirow{2}{*}{$\begin{array}{l}\text { High sensitivity to food/ waterborne } \\
\text { diseases and extreme events (natural } \\
\text { disasters) }\end{array}$} & Scenario A: Very Low & Very High \\
\hline & & Scenario B: Low & High \\
\hline
\end{tabular}

\section{Discussion}

\subsection{Projections for Future Vulnerability}

Yemen is highly vulnerable to climate change and its impact on the population health. The vulnerability of Yemeni population is a combination of its exposure to climate-related hazards, sensitivity, and the adaptation measures to the projected climate change (IPPC, 2012. AR5). Sensitivity to climate change stressors are determined by their biological traits which include the overall health status, age, and life stage in addition to other factors such as population density, level of economic development, food availability, income level and distribution, local environmental conditions, preexisting health status, the availability and quality of health care and services and the population's accessibility to these services (WHO \& UNEP, 2003).

Regarding Yemen, both population growth and climate change are inevitably occurring and these two factors are the main determinants of vulnerability. Other factors that will determine future health vulnerability include; the low current public health status, the age - sex structure of the population, very low socioeconomic development status and the unstable political and security stability of government.

The projected proportion of population 65 years and above in 2080 will form $14.2 \%$ of the total population of which $6.4 \%$ will be men and $7.8 \%$ will be women, whereas the projected proportion in 2100 will form $19.9 \%$ of which $8.8 \%$ will be men and $11.1 \%$ will be women. This will bring an increase in the prevalence of chronic diseases such as cardiovascular, renal and respiratory diseases all of which are sensitive to climate change and hence the patterns of mortality and morbidity and health expenditure will be changed.

Because population growth is linked to climate change vulnerability, even if nothing else has been changed, and because Yemen is characterized by a very low HDI, a widespread hunger, high percentage of under-nutrition, weak, poor and low coverage of health care, poor physical infrastructures, lack of safe water supply, poor sanitation and poor waste management will, together, form the main entrance of the future vulnerability of all population and all of which would need policies and structural arrangements in all government sectors which should be aimed to improve health, education, balanced population growth and economic development. 


\subsection{Future Vulnerability to Flood}

According to the Emergency Events database (EM-DAT) approximately 100,000 people are affected annually by disasters triggered by natural hazards in Yemen. In terms of exposure hazards, floods are the most important and recurring disaster in Yemen and it is expected that more people will be exposed to floods and it is very likely that health losses caused by storms and floods will increase this century if no adaptation measures are taken, but it is not clear by how much the projected increase can be attributed to climate change (IPPC, 2013). Flash floods is ranked as the top four natural disasters in Yemen since 1990 in regard to economic damages, eight of the top 10 in regard to killed persons, and nine of the top 10 in regard to the affected people (CRED, http://www.emdat.be/).

\subsection{Future Vulnerability to Drought}

Climate change may increase the length of the dry periods that result in widespread drought, land degradation and desertification. Water stress is observed to be increasing and the groundwater reserves are most likely to be depleted in two to three decades regardless of climate change leading to reduction of agricultural output by up to $40 \%$. High aridity, fast-depleting reserved groundwater and projected increases in temperature indicate more stress on agricultural production. Greater rainfall variability could result in prolonged drought periods (WB, 2010).

Moreover, the future effect of drought will indirectly affect the health of the society specially women and children mainly in the rural areas. The distance travelled to collect water during the drought terms will be doubled or four folded. Children in general, but specifically girls, will be forced to leave school and help their mothers for bringing water for house consumption and this will have its implication on socioeconomic development of the society leading to more poverty, illiteracy and ill health.

\subsection{Future Vulnerability to Malaria Disease}

Models for predicting the effects of climate change on vector-borne diseases are subjected to a high degree of uncertainty due to 1) vector-borne diseases are maintained in nature in complex transmission cycles that involve vectors, intermediate hosts, and humans; and 2) there are a number of other significant social and environmental drivers of transmission of vector-borne disease in addition to climate change. For example, while climate variability and climate change both alter the transmission of vector-borne diseases, they will likely interact with many other factors, including how pathogens adapt and change, the availability of hosts, ecosystems changing and land use, demographics, human behavior, and adaptive capacity (IOM, 2003, Allan et al, 2005), and these complex interactions make it difficult to predict the effects of climate change on vector-borne diseases.

The influence of temperature on malaria development appears to be nonlinear, and is vector specific (Alonso et al., 2011). Increased temperature variations, when the maximum is close to the upper limit for vector and pathogen, tend to reduce transmission, while increased variations of mean daily temperature near the minimum boundary increase transmission (Paaijmans et al., 2010). The strongly nonlinear response to temperature means that even modest warming may drive large increases in transmission of malaria, if conditions are otherwise suitable (Pascual et al., 2006; Alonso et al., 2011). On the other hand, at relatively high temperatures, modest warming may reduce the potential of malaria transmission (Lunde et al., 2013).

Using the A1B climate change scenario, projecting the population at risk of malaria in 2030 and 2050 with GDP per capita held constant at 2010 values, the model projected 5.2 billion people at risk in 2050, out of a predicted global population of 8.5 billion. Keeping climate constant, and assuming strong economic growth allied with social development ("best case"), the model projected 1.74 billion people at risk (approximately half the present number at risk) in 2050 (Beguin et al., 2011).

\subsection{Future Vulnerability to Diarrheal Diseases}

A projected increase of $8 \%$ to $11 \%$ in the risk of diarrhea in the tropics and subtropics in 2039 due to climate change (Kolstad and Johansson, 2011). In Botswana, if hot, dry conditions begin earlier in the year, and are prolonged, as projected by down-scaled climate scenarios, the present dry season peak in diarrheal disease may be amplified (Alexander et al., 2013). However, the same analysis projected that incidence of diarrheal disease in the wet season would decline.

A. constructed a mechanistic model of the transmission cycle of S. mansoni reported a peak in the worm burden in humans at an ambient temperature of $30^{\circ} \mathrm{C}$, falling sharply as temperature rises to $35^{\circ} \mathrm{C}$. This is attributed to the increasing mortality of both the snails and the water-borne intermediate forms of the parasite, and noted that worm burden is not directly linked to the prevalence of schistosomiasis (Mangal et al.,2008).

Depending on the assumption of Scenario A with persistence of the same current health care system and the same existing standards of living but with high population growth rate and the remaining of economic growth at slow or moderate rates, and taking into consideration the assumption of Scenario B that is dependent on improving the current health care system and the existing standards of living with both population growth and the economic growth growing moderately, the overall impact of climate change on the different vulnerable population group is shown in the below table: 
Table (4): the overall impact of climate change on vulnerable population groups in Yemen

\begin{tabular}{|c|c|c|c|c|c|c|c|}
\hline $\begin{array}{l}\text { Vulnerable } \\
\text { groups }\end{array}$ & $\begin{array}{c}\text { Climate } \\
\text { effect }\end{array}$ & \multicolumn{2}{|c|}{$\begin{array}{l}\text { Socioeconomic } \\
\text { Scenarios }\end{array}$} & Climatic & Climate & \multicolumn{2}{|c|}{ Overall impact } \\
\hline \multirow{2}{*}{ Children } & \multirow{2}{*}{$\begin{array}{c}\text { Under } 5 \\
\text { years } \\
\text { malnutrition }\end{array}$} & $\begin{array}{c}\text { Scenario } \\
\mathrm{A}^{*}\end{array}$ & $\begin{array}{c}\text { Scenario } \\
\mathrm{B}^{*}\end{array}$ & \multirow{2}{*}{$\begin{array}{l}\text { Increase in } \\
\text { temperature }\end{array}$} & \multirow{2}{*}{$\begin{array}{l}\text { High } \\
\text { increase }\end{array}$} & $\begin{array}{c}\text { Scenario } \\
\text { A }\end{array}$ & $\begin{array}{c}\text { Scenario } \\
\text { B }\end{array}$ \\
\hline & & $\begin{array}{c}\text { High } \\
\text { increase }\end{array}$ & $\begin{array}{l}\text { Moderate } \\
\text { Increase }\end{array}$ & & & $\begin{array}{c}\text { High } \\
\text { increase }\end{array}$ & $\begin{array}{c}\text { Moderate } \\
\text { increase }\end{array}$ \\
\hline \multirow[t]{2}{*}{ Women } & \multirow{2}{*}{$\begin{array}{c}\text { Heat stress } \\
\text { related } \\
\text { diseases }\end{array}$} & $\begin{array}{c}\text { Scenario } \\
\mathrm{A}^{*}\end{array}$ & $\begin{array}{c}\text { Scenario } \\
\mathrm{B}^{*}\end{array}$ & \multirow{2}{*}{$\begin{array}{l}\text { Increase in } \\
\text { temperature }\end{array}$} & \multirow{2}{*}{$\begin{array}{l}\text { High } \\
\text { increase }\end{array}$} & $\begin{array}{c}\text { Scenario } \\
\text { A }\end{array}$ & $\begin{array}{c}\text { Scenario } \\
\text { B }\end{array}$ \\
\hline & & $\begin{array}{c}\text { High } \\
\text { increase }\end{array}$ & $\begin{array}{l}\text { Moderate } \\
\text { Increase }\end{array}$ & & & $\begin{array}{c}\text { High } \\
\text { increase }\end{array}$ & $\begin{array}{c}\text { Moderate } \\
\text { increase }\end{array}$ \\
\hline \multirow{2}{*}{$\begin{array}{l}\text { Pregnant } \\
\text { Women }\end{array}$} & \multirow{2}{*}{$\begin{array}{c}\text { Heat stress } \\
\text { related } \\
\text { diseases }\end{array}$} & $\begin{array}{c}\text { Scenario } \\
A^{*}\end{array}$ & $\begin{array}{c}\text { Scenario } \\
\mathrm{B}^{*}\end{array}$ & \multirow{2}{*}{$\begin{array}{l}\text { Increase in } \\
\text { temperature }\end{array}$} & \multirow{2}{*}{$\begin{array}{l}\text { High } \\
\text { increase }\end{array}$} & $\begin{array}{c}\text { Scenario } \\
\text { A }\end{array}$ & $\begin{array}{c}\text { Scenario } \\
\text { B }\end{array}$ \\
\hline & & $\begin{array}{c}\text { High } \\
\text { increase }\end{array}$ & $\begin{array}{l}\text { Moderate } \\
\text { Increase }\end{array}$ & & & $\begin{array}{c}\text { High } \\
\text { increase }\end{array}$ & $\begin{array}{c}\text { Moderate } \\
\text { increase }\end{array}$ \\
\hline \multirow{2}{*}{$\begin{array}{l}\text { Elderly } \\
\text { People }\end{array}$} & \multirow{2}{*}{$\begin{array}{c}\text { Heat related } \\
\text { deaths and } \\
\text { injuries }\end{array}$} & $\begin{array}{c}\text { Scenario } \\
A^{*}\end{array}$ & $\begin{array}{c}\text { Scenario } \\
\text { B }^{*}\end{array}$ & \multirow{2}{*}{$\begin{array}{l}\text { Increase in } \\
\text { temperature }\end{array}$} & \multirow{2}{*}{$\begin{array}{c}\text { High } \\
\text { increase }\end{array}$} & $\begin{array}{c}\text { Scenario } \\
\text { A }\end{array}$ & $\begin{array}{c}\text { Scenario } \\
\text { B }\end{array}$ \\
\hline & & $\begin{array}{c}\text { High } \\
\text { increase }\end{array}$ & $\begin{array}{l}\text { Moderate } \\
\text { Increase }\end{array}$ & & & $\begin{array}{c}\text { High } \\
\text { increase }\end{array}$ & $\begin{array}{c}\text { High } \\
\text { increase }\end{array}$ \\
\hline \multirow{2}{*}{ Outdoor } & \multirow{2}{*}{$\begin{array}{l}\text { Heat } \\
\text { Stroke }\end{array}$} & $\begin{array}{c}\text { Scenario } \\
\mathrm{A}^{*}\end{array}$ & $\begin{array}{c}\text { Scenario } \\
\mathrm{B}^{*} \\
\end{array}$ & \multirow{2}{*}{$\begin{array}{l}\text { Increase in } \\
\text { temperature }\end{array}$} & \multirow{2}{*}{$\begin{array}{l}\text { High } \\
\text { increase }\end{array}$} & $\begin{array}{c}\text { Scenario } \\
\text { A }\end{array}$ & $\begin{array}{c}\text { Scenario } \\
\text { B } \\
\end{array}$ \\
\hline & & $\begin{array}{l}\text { Moderate } \\
\text { increase }\end{array}$ & $\begin{array}{l}\text { Moderate } \\
\text { Increase }\end{array}$ & & & Stable & $\begin{array}{c}\text { Moderate } \\
\text { increase }\end{array}$ \\
\hline \multirow{2}{*}{$\begin{array}{l}\text { Population } \\
\text { with low } \\
\text { SES }\end{array}$} & \multirow{2}{*}{$\begin{array}{l}\text { Chronic } \\
\text { diseases }\end{array}$} & $\begin{array}{c}\text { Scenario } \\
\mathrm{A}^{*}\end{array}$ & $\begin{array}{c}\text { Scenario } \\
\mathrm{B}^{*}\end{array}$ & \multirow{2}{*}{$\begin{array}{l}\text { Increase in } \\
\text { temperature } \\
\text { and flood } \\
\text { risk }\end{array}$} & \multirow{2}{*}{$\begin{array}{l}\text { Moderate } \\
\text { increase }\end{array}$} & $\begin{array}{c}\text { Scenario } \\
\text { A }\end{array}$ & $\begin{array}{c}\text { Scenario } \\
\text { B } \\
\end{array}$ \\
\hline & & $\begin{array}{c}\text { High } \\
\text { Increase }\end{array}$ & $\begin{array}{l}\text { Moderate } \\
\text { increase }\end{array}$ & & & $\begin{array}{c}\text { High } \\
\text { increase }\end{array}$ & $\begin{array}{c}\text { High } \\
\text { increase }\end{array}$ \\
\hline \multirow[t]{2}{*}{ IDPs } & \multirow{2}{*}{$\begin{array}{l}\text { Vectorborne } \\
\text { Diseases }\end{array}$} & $\begin{array}{c}\text { Scenario } \\
\mathrm{A}^{*}\end{array}$ & $\begin{array}{c}\text { Scenario } \\
\mathrm{B}^{*}\end{array}$ & \multirow{2}{*}{$\begin{array}{l}\text { Increase in } \\
\text { temperature }\end{array}$} & \multirow{2}{*}{$\begin{array}{l}\text { High } \\
\text { increase }\end{array}$} & $\begin{array}{c}\text { Scenario } \\
\text { A }\end{array}$ & $\begin{array}{c}\text { Scenario } \\
\text { B }\end{array}$ \\
\hline & & $\begin{array}{c}\text { High } \\
\text { Increase }\end{array}$ & $\begin{array}{c}\text { Moderate } \\
\text { increase }\end{array}$ & & & $\begin{array}{c}\text { High } \\
\text { increase }\end{array}$ & $\begin{array}{c}\text { High } \\
\text { increase }\end{array}$ \\
\hline
\end{tabular}

\section{Conclusion}

The extent of the impact of climate change on the population health is determined to a large extent by the socioeconomic scenarios, and the impact on health would be more severe under scenario A than scenario B which indicates the needs for higher adaptive capacity in the health care sector.

Yemen is a disaster-prone country and faces a number of natural hazards. Exposure to these climate related hazards are expected to severely exacerbate health problems such as vectorborne and waterborne diseases which may extend their range into areas that are presently unaffected as well as chronic diseases such as cardiac, respiratory and renal disease. The largest risks will apply in populations that are currently most affected by climate related diseases and hence it is expected that health losses due to climate change-induced under-nutrition will occur mainly in areas that are already food-insecure (IPPC, 2013).

Minimizing the consequences of recent war and taking into account the 2010 health indicators as a base year, the degree to which current health programs and measures will need modification to address additional pressures from climate change will depend on the current burden of ill health; the effectiveness of current interventions; projections of where, when, and how the health burden could change with climate change; the feasibility of implementing additional programs; other stressors that could increase or decrease resilience; and the social, economic, and political context for intervention (Ebi et al., 2006).

Incremental adaptation includes improving public health and health care services for climate-related health outcomes, without necessarily considering the possible impacts of climate change (IPCC, 2013). Rebuilding and maintaining of public health infrastructure are often viewed as the "most important, cost-effective and urgently needed" adaptation strategy to climate change in the human health sector (IPCC, 2001). These include public health training, effective surveillance and emergency response systems, and sustainable prevention and control programs (WHO \& UNEP, 2003). 


\section{References}

1. Abuaku, B.K., J. Zhou, X. Li, S. Li, A. Liu, T. Yang, and H. Tan, 2009: Morbidity and mortality among populations suffering floods in Hunan, China: the role of socioeconomic status. Journal of Flood Risk Management, 2(3), 222-228.

2. Alexander, K.A., M. Carzolio, D. Goodin, and E. Vance, 2013: Climate change is likely to worsen the public health threat of diarrheal disease in Botswana. International Journal of Environmental Research and Public Health, 10(4),1202-1230.

3. Al-Taiar, A., J. Shabbar, A. Assabri, M. Al-Hobary, A. Azazy, N. Al-Mahdi, K. Ameen, B.M. Greenwood, and C.J.M. Whitty (2006). 'Severe malaria in children in Yemen: two site observational study'. BMJ. 333:827

4. Al-Taiar, A., J. Shabbar, A. Assabri, M. Al-Hobary, A. Azazy, A. Al-Gabri, M. Al-Ganadi, B. Attal, and C.J.M. Whitty (2008). 'Who develops severe malaria- Impact of access to healthcare, socio-economic and environmental factors in Yemen: a case-control study'. Tropical Medicine \& International Health 13(6):762770 .

5. Acosta-Michlik, L., U. Kelkar, and U. Sharma, 2008: A critical overview: local evidence on vulnerabilities and adaptations to global environmental change in developing countries. Global Environmental Change, 18(4), 539-542.

6. Al-Mansoob, M.A. and M.M. Al-Mazzah (2005). 'The role of climate on Malaria Incidence Rate in four governorates of Yemen'. Medical Journal of Malaysia. 60(3):349-57.

7. Anthony G. Patt, Mark Tadross, Patrick Nussbaumer, Kwabena Asante, Marc Metzger, Jose Rafael, Anne Goujon, and Geoff Brundrit, 2010. Estimating least-developed countries' vulnerability to climate-related extreme events over the next 50 years. PNAS January 26, 2010107 (4) 1333-1337.

8. Alonso, D., M.J. Bouma, and M. Pascual, 2011: Epidemic malaria and warmer temperatures in recent decades in an East African highland. Proceedings of the Royal Society B, 278(1712), 1661-1669.

9. Bassiouny, H. K. (2001). 'Bioenvironmental and meteorological factors related to the persistence of malaria in Fayoum Governorate: A retrospective study’. Eastern Mediterranean Health Journal 7(6):895-906.

10. Basu, R. and B.D. Ostro, 2008: A multicounty analysis identifying the populations vulnerable to mortality associated with high ambient temperature in California. American Journal of Epidemiology, 168(6), 632-637.

11. Berry, H.L., K. Bowen, and T. Kjellstrom, 2010: Climate change and mental health: a causal pathways framework. International Journal of Public Health, 55(2), 123- 132.

12. Brouwer, R., S. Akter, L. Brander, and E. Haque, 2007: Socioeconomic vulnerability and adaptation to environmental risk: a case study of climate change and flooding in Bangladesh. Risk Analysis, 27(2), 313-326.

13. Brunkard, J., G. Namulanda, and R. Ratard, 2008: Hurricane Katrina deaths, Louisiana, 2005. Disaster Medicine and Public Health Preparedness, 2(4), 215-223.

14. Confalonieri et al., 2007; McMichael et al., 2003a; WHO, 2002, 2009. Protecting Health from Climate Change: Vulnerability and Adaptation Assessment.

15. Cook, J.T. and D.A. Frank, 2008: Food security, poverty, and human development in the United States. Annals of the New York Academy of Sciences, 1136(1), 193- 209.

16. Corvalan, C et al. (2000). Decision Making in Environmental Health: From Evidence to Action. E \& FN Spon, London

17. Ebi, K.L., J. Smith, I. Burton, and J. Scheraga, 2006: Some lessons learned from public health on the process of adaptation. Mitigation Adaptation Strategies Global Change, 11, 607-620.

18. EPA (2009). National Adaptation Program of Action on Climate Change (UNFCCC), 2009. Environmental Protection Authority, Sana' a, Yemen.

19. EPC (2001). Initial Communication of Yemen to the United Nations Framework on Climate Change (UNFCCC), April 2001. Environmental Protection Council, Sana' a, Yemen.

20. Fankhauser, S. and R.S.J. Tol (1997). 'The social costs of climate change: the IPCC Second Assessment Report and beyond'. Mitigation and Adaptation Strategies for Global Change.1:385-403.

21. Fouillet, A., G. Rey, V. Wagner, K. Laaidi, P. Empereur-Bissonnet, A. Le Tertre, P. Frayssinet, P. Bessemoulin, F. Laurent, P. De Crouy-Chanel, E. Jougla, and D. Hemon, 2008: Has the impact of heat waves on mortality changed in France since the European heat wave of summer 2003? A study of the 2006 heat wave. International Journal of Epidemiology, 37(2), 309-317.

22. Gamble, J.L., B.J. Hurley, P.A. Schultz, W.S. Jaglom, N. Krishnan, and M. Harris, 2013: Climate change and older Americans: state of the science. Environmental Health Perspectives, 121(1), 15-22.

23. Khamsi, R. (2006). 'Small heat rise may offer big boost for malara', New Scientist, 20 March 2006

24. Kovats, R.S. and S. Hajat, 2008: Heat stress and public health: a critical review. Annual Review of Public Health, 29, 41-55.

25. Lunde, T.M., M.N. Bayoh, and B. Lindtjorn, 2013: How malaria models relate temperature to malaria transmission. Parasites \& Vectors, 6, 20

26. Mangal, T.D., S. Paterson, and A. Fenton, 2008: Predicting the impact of long-term temperature changes on 
the epidemiology and control of schistosomiasis: a mechanistic model. PLoS One, 3(1), e1438

27. Malik, S.M., H. Awan, and N. Khan, 2012: Mapping vulnerability to climate change and its repercussions on human health in Pakistan. Globalization and Health, 8, 31, doi:10.1186/1744-8603-8-31.

28. McGeehin and Mirabelli, 2007. Climate Change and Extreme Heat Events. American Journal of preventive Medicine. 35(5), 429-435

29. Nicole Glass, (2012). The Water Crisis in Yemen: Causes, Consequences and Solutions, Global Majority EJournal, Vol. 1, No. 1 (June 2010), pp. 17-30

30. Neelormi, S., N. Adri, and A. Ahmed, 2009: Gender dimensions of differential health effects of climate change induced water-logging: a case study from coastal Bangladesh. Proceedings of IOP Conference Series: Earth

31. Nitschke, M., G. Tucker, A. Hansen, S. Williams, Y. Zhang, and B. Peng, 2011: Impact of two recent extreme heat episodes on morbidity and mortality in Adelaide, South Australia: a case-series analysis. Environmental Health, 10(1), 42-51.

32. N J Shanks 1, G Papworth, 2001. Environmental factors and heatstroke. https://pubmed.ncbi.nlm.nih.gov

33. Paaijmans, K.P., S. Blanford, A.S. Bell, J.I. Blanford, A.F. Read, and M.B. Thomas, 2010: Influence of climate on malaria transmission depends on daily temperature variation. Proceedings of the National

34. Pascual, M., J.A. Ahumada, L.F. Chaves, X. Rodo, and M. Bouma, 2006: Malaria resurgence in the East African highlands: temperature trends revisited. Proceedings of the National Academy of Sciences of the United States of America, 103(15), 5829-5834.

35. Patt, A.G., M. Tadross, P. Nussbaumer, K. Asante, M. Metzger, J. Rafael, A. Goujon, and G. Brundrit, 2010: Estimating least-developed countries' vulnerability to climate related extreme events over the next 50 years. Proceedings of the National Academy of Sciences of the United States of America, 107(4), 1333-1337

36. Patz J.A., Strzepek K., Lele S., Hedden M., Greene S., Noden B., Hay S.I., Kalkstein L., Beier J.C. (1998), "Predicting key malaria transmission factors, biting and entomological inoculation rates, using modeled soil moisture in Kenya", Tropical Medicine and International Health, 3, 818-827.

37. Peduzzi, P., B. Chatenoux, H. Dao, A. De Bono, C. Herold, J. Kossin, F. Mouton, and O. Nordbeck, 2012: Global trends in tropical cyclone risk. Nature Climate Change, 2(4), 289-294.

38. Perera, F.P., 2008: Children are likely to suffer most from our fossil fuel addiction. Environmental Health Perspectives, 116(8), 987-990.

39. Potts, M. and C.E. Henderson, 2012: Global warming and reproductive health. International Journal of Gynecology \& Obstetrics, 119, 564-567.

40. Ramin, B.M. and A.J. McMichael, 2009: Climate change and health in sub-Saharan Africa: a case-based perspective. Ecohealth, 6(1), 52-57

41. Ranjit, S. and N. Kissoon, 2011: Dengue hemorrhagic fever and shock syndromes. Pediatric Critical Care Medicine, 12(1), 90-100.

42. Saab, A. (2009). 'Climate Change and Human Rights: The Impact of Climate Change on the Right to the Highest Attainable Standard of Health', L.L.M dissertation, King's College London.

43. Smith, K.R., A. Woodward, D. Campbell-Lendrum, D.D. Chadee, Y. Honda, Q. Liu, J.M. Olwoch, B. Revich, and R. Sauerborn, 2014: Human health: impacts, adaptation, and co-benefits. In: Climate Change 2014: Impacts, Adaptation, and Vulnerability. Part A: Global and Sectoral Aspects. Contribution of Working Group II to the Fifth Assessment Report of the Intergovernmental Panel on Climate Change

44. WHO, 2011: Gender, Climate Change and Health. Public Health \& Environment Department (PHE), Health Security \& Environment Cluster (HSE), World Health Organization (WHO), Geneva, Switzerland, 36 pp.

45. Wilby, R. (2009). An evaluation of climate data and downscaling options for Yemen

46. World Bank Yemen study (2010): Assessing the Impact of Climate Change and variability on the Water and Agriculture Sectors, and the Policy Implications, 2010.

\section{Special Reports}

1. World Health Organization (2013). Protecting health from climate change: vulnerability and adaptation assessment

2. Intergovernmental Panel on Climate Change (2013). Fifth Assessment Report, Working Group II

3. Intergovernmental Panel on Climate Change (2007). Fourth Assessment Report, Working Group II

4. UNDP (2015). Climate Change Country Profile: Yemen.

\section{Arabic Reports and Documents related to the MoPHP}

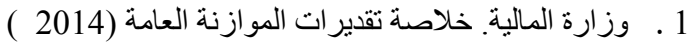

2 ـ . وزارة الصحة العامة والسكان. التقرير الإحصائي السنوي (2014)

\section{English Reports and Documents related to the MoPHP}

1. Ministry of Public Health and Population Malaria control Program Reports 2003 - 2013 
2. Ministry of Public Health and Population Yemen Demographic health surveys, 2013.

3. Ministry of Public Health and Population. Malaria Country Profiles Yemen 2005 - 2014

4. Ministry of Public health and population. National Health Strategy $2010-2025$

5. Ministry of Public Health and Population. National Health Strategy, 2010-2025.

6. Ministry of Public health and population. The Fourth 5-Year Health Development \& Poverty Alleviation Plan $2011-2015$

7. Ministry of Public health and population. The Third 5-Year Health Development \& Poverty Alleviation Plan $2011-2015$

8. Ministry of Public Health and Population. Yemen Family health survey 2003

9. Yemen census 1994 and 2004

\section{Websites}

1. Central Statistical Office Data Base, 2015: http://www.tradingeconomics.com/yemen/gdp-growth-annual

2. Drought Conditions and Management Strategies in Yemen, 2014 http://www.ais.unwater.org/ais/pluginfile.php/605/mod_page/content/23/Yemen.pdf

3. European Commission (2015): Yemen ECHO Factsheet: http://ec.europa.eu/echo/files/aid/countries/factsheets/yemen_en.pdf

4. Republic of Yemen and Health Metrics Network. Health Information Systems Assessment Report. The Ministry of Public Health and Population, Sana'a, Yemen, 2009. http://www.who.int/healthmetrics/library/countries/HMN_YEM_Assess_Final_2009_07_en.pdf)

5. Transparency International (2014) http://www.transparency.org/cpi2014/results

6. UNDESA (2012): World Population Prospects: The 2012 Revision: http://esa.un.org/wpp/unpp/panel_population.htm

7. UNDP (2015). http://hdr.undp.org/en/content/table-1-human-development-index-and-its-components.

8. UNDP (2015). http://hdr.undp.org/en/content/table-4-gender-inequality-index

9. WHO \& UNEP. (2003). Climate change and human health - risks and responses. Summary (Adobe Digital Editions version), Retrieved from ttp:// www.who.int/globalchange/publications/cchhbook/en/

10. WHO, 2015),http://reliefweb.int/report/yemen/yemen-conflict-situation-report-14-31-august-13september-2015

11. WHO, June 2015. http://reliefweb.int/report/yemen/dengue-yemen-palais-briefing-notes-12-june-2015

12. World Bank Data (2015) - GDP per capita., http://data.worldbank.org/indicator/NY.GDP.PCAP.PP.CD

13. World Health Organization $(2008-2013)$. Country Cooperation Strategy for the Republic of Yemen. 